\title{
EFFECT OF ACCREDITATION ON OCCUPATIONAL HEALTH AND SAFETY BEHAVIOR AMONG WORKERS IN A PRIVATE HOSPITAL, SEMARANG, CENTRAL JAVA
}

\author{
Haryanto, Hanifa Maher Denny, Suroto \\ Occupational Health and Safety Promotion Unit, Masters in Public Health, \\ Faculty of Public Health, Universitas Diponegoro
}

\begin{abstract}
Background: Hospital is a health care industry with a variety of complex labor problems and various risks of occupational disease and accident. Accreditation is a way to protect patients, visitors, caregivers from accidents and occupational diseases. This study aimed to analyze the effect of accreditation on occupational health and safety behavior among workers in a private hospital, Semarang, Central Java.

Subjects and Method: This was a case study conducted at a private hospital, Semarang, Central Java. A total of 8 people were selected for this study as main informants and 3 people as triangulation informants (team leader of occupational health and safety, head of hospital accreditation, and the head of hospital facilities and infrastructure maintenance). The data were collected by in-depth interviews, direct observation, and document review. The data were analyzed using the stages of data reduction, data display, content analysis, and decision-making.

Results: After the accreditation, the hospital had only minimally implemented policies and regulations of occupational safety and health. Some of employees did not use personal protective equipment while working at a hazardous place. Some occupational safety and health facilities were poorly maintained. Equipment that requires large funds was gradually completed.

Conclusion: Occupational health and safety has not been well implemented after hospital accreditation. The hospital management has yet to apply reward and sanction related to occupational safety and health for employees.
\end{abstract}

Keywords: accreditation, hospital, occupational safety and health behavior

\section{Correspondence:}

Haryanto. Occupational Health and Safety Promotion Unit, Masters in Public Health, Faculty of Public Health, Universitas Diponegoro, Semarang, Central Java. Email: haryantoroemani@gmail.com._Mobile: 08122921644.

The $5^{\text {th }}$ International Conference on Public Health

Best Western Premier Hotel, Solo, Indonesia, February 13-14, 2019 | 55 https://doi.org/10.26911/theicph.2019.01.01 